\title{
OBSERVATIONS ON THE ETIOLOGIC RELATIONSHIP OF ACHYLIA GASTRICA TO PERNICIOUS ANEMIA. VII. RESEMBLANCES BETWEEN THE PROTEO- LYTIC ACTIVITY OF NORMAL HUMAN GASTRIC JUICE ON CASEIN IN NEUTRAL SOLUTION AND THE ACTIVITY OF THE INTRINSIC FACTOR ${ }^{1}$
}

\author{
By F. H. L. TAYLOR, W. B. CASTLE, ROBERT W. HEINLE AND MARGARET A. ADAMS
}

(From the Thorndike Memorial Laboratory, Second and Fourth Medical Services (Harvard), Boston City Hospital, and the Department of Medicine, Harvard Medical School, Boston)

(Received for publication January 22, 1938)

A. CORRELATION OF THE in vitro ACTIVITY OF GASTRIC JUICE ON CASEIN AT PH 7.4 WITH THE CLINICAL ACTIVITY OF THE GASTRIC INTRINSIC FACTOR

It has been shown $(1,2)$ that the oral administration of normal human gastric juice (intrinsic factor) together with beef muscle (extrinsic factor) causes increased blood production and clinical improvement in patients with addisonian pernicious anemia. Positive effects appear if a mixture of beef muscle and gastric juice, with or without preliminary incubation, is administered to the patient at $\mathrm{pH} 5$ or 7 (2). Since neither beef muscle (1) nor gastric juice $(2,3$, $4,5,6,7)$ when administered alone has a positive effect on blood production, it has been inferred that an interaction between these substances is essential for hematopoiesis $(2,3,7)$. Such clinical evidence, however, does not serve to indicate whether this interaction occurs in vitro, within the alimentary tract, or parenterally.

Until very recently, no evidence has been obtained of any chemical activity in vitro in neutral mixtures of beef muscle and gastric juice. Unpublished experiments made in 1930, in collaboration with Dr. C. W. Heath, on mixtures of beef muscle and gastric juice incubated in vitro at $\mathrm{pH}$ 7.4 resulted in no detectable increases in the amino nitrogen content of the mixture. Klein and Wilkinson's (8) claim that they have demonstrated the synthesis of the thermostable principle of liver by in vitro interaction of beef muscle and intrinsic factor from hog's gastric mucosa has not been sustained in our hands when

\footnotetext{
1 The expenses of this investigation were defrayed in part by a gift to Harvard University from Smith, Kline and French Laboratories, Philadelphia, and by the J. K. Lilly gift to the Harvard Medical School.
}

mixtures of beef muscle and gastric juice were so employed (9). In 1934, however, Griffiths (10) reported increases in total nitrogen in trichloracetic acid filtrates of digests of normal human gastric juice incubated at $\mathrm{pH} 6$ with beef muscle globulin. He differentiated this activity from that of trypsin and pepsin only on the basis of the reaction of the mixture. Because of the smaller amounts of nitrogen freed by the secretions of patients with pernicious anemia, he pointed out the possibility of identity of this activity of normal human gastric juice with that of the so-called gastric intrinsic factor. Emerson and Helmer (11) subsequently attributed the proteolysis described by Griffiths to a combination of slight peptic activity at $\mathrm{pH} 6$ and differential adsorption of nonprotein substances by the proteins of the digest.

The results of recent clinical observations (9), however, suggest that some essential interaction between beef muscle and normal gastric juice does occur within the alimentary tract of the patient with pernicious anemia. When a mixture of 200 grams of beef muscle and $150 \mathrm{ml}$. of normal gastric juice was incubated for 6 hours at $\mathrm{pH}$ 1.8 or 2.5 and was given daily at $\mathrm{pH} 1.8$ or 2.5 to patients with pernicious anemia, increased blood production failed to occur, but when the mixture was given at $\mathrm{pH} 5$ or 7 following such acid incubation for 6 or for 12 hours, increased blood production did appear. Thus, incubation in this acid medium for 12 hours apparently did not destroy intrinsic factor. Instead, it appears probable that the acid reaction of the mixture, maintained after administration to the patient by the buffering properties of the beef muscle protein, failed to provide the more nearly neutral environment suitable for the essential interaction of the beef muscle and gastric juice. Since the inhibi- 
tory effect of the acid reaction could scarcely have been exerted after absorption of these substances from the alimentary tract had taken place, it was inferred that in the hematopoietically active neutralized mixtures of beef muscle and gastric juice some essential reaction took place within the alimentary tract or, conceivably, in vitro.

Accordingly, a reinvestigation of the in vitro activity of normal human gastric juice at $\mathrm{pH} 7.4$ was undertaken. Washed casein was selected as a convenient substrate. As in former experiments with beef muscle, no significant increase in the amino nitrogen in the digests was observed. However, the increasing turbidity of the filtrates, obtained after precipitation of the digests by trichloracetic acid, drew attention to a corresponding progressive increase in total nitrogen. In a preliminary publication (12) a summary has been presented of the resemblances between the conditions essential for this activity and for the clinical activity of intrinsic factor. The present communication reports in detail the data from those observations, together with a further study of the nature of the action of gastric juice on casein at $\mathrm{pH} 7.4$.

\section{Methods}

A 1 per cent solution of sodium caseinate was prepared as follows: 1 gram of washed casein (A. H. Thomas and Co.) was suspended in $20 \mathrm{ml}$. of water. Ten ml. of $2.5 \mathrm{~N}$ sodium hydroxide were added and the suspension shaken in order to effect solution of the casein. Normal hydrochloric acid (approximately 22 ml.) was then added slowly to the point of incipient precipitation and a final adjustment to $\mathrm{pH} 7.4$ was made with $\mathrm{N} / 10$ hydrochloric acid. Finally, the casein solution was diluted with distilled water to a volume of $100 \mathrm{ml}$.

Fresh gastric juice or other preparations were brought to approximately $\mathrm{pH} 7.4$ with normal sodium hydroxide solution and final adjustment to this $\mathrm{pH}$ was made with $\mathrm{N} / 10$ sodium hydroxide. Fifty $\mathrm{ml}$. of such material were rapidly mixed in an Erlenmeyer flask with $50 \mathrm{ml}$. of the 1 per cent casein solution. The mixture was adjusted

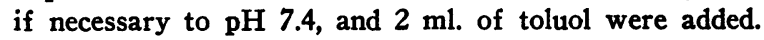
The flasks were set in a constant temperature bath at $37.5^{\circ} \mathrm{C}$. for 24 hours. The reaction of the digest at no time fell below $\mathrm{pH} 7$. Plate cultures at the end of 24 hours were negative although occasionally turbidities appeared in broth cultures.

Five ml. samples of the digest were removed immediately and at certain intervals for 24 hours. Each sample was at once precipitated by $20 \mathrm{ml}$. of 10 per cent trichloracetic acid, and, after standing for 15 minutes, was filtered through Number 12 Whatman folded paper. No attempt was made to remove the colloidal material present in the filtrates, which were then subjected to micro-Kjeldahl digestion, using potassium persulphate as a secondary oxidizing agent. Subsequently, after alkalinization, the nitrogen was removed by distillation and determined colorimetrically by nesslerization of the distillate.

Ten ml. samples were removed immediately and at intervals for formol titration. The reaction of the formaldehyde solution was such that one drop of $\mathrm{N} / 10$ sodium hydroxide would bring $5 \mathrm{ml}$. of the solution to the phenolphthalein end point. After adjusting the reaction of the $10 \mathrm{ml}$. digest sample to the phenolphthalein end point; $5 \mathrm{ml}$. of 30 per cent formaldehyde solution were added, the flasks were shaken, and the acid developed was titrated with $\mathrm{N} / 10$ sodium hydroxide.

The total nitrogen per $100 \mathrm{ml}$. of digest produced by the action of the gastric juice or other preparations on casein was calculated by subtracting the total nitrogen of the trichloracetic acid filtrate of the initial sample from that found in each subsequent sample expressed as milligrams of nitrogen per $100 \mathrm{ml}$. of digest. The amino nitrogen produced was calculated in a similar manner from the initial and subsequent formol titration values.

\section{Results}

The effect of incubation of normal human gastric juice with casein solution at $p H$ 7.4. Normal fasting subjects were injected intramuscularly with $0.5 \mathrm{mgm}$. of histamine phosphate. The gastric secretion was collected during the next hour and kept in the ice box until required for use later during the same day. Samples of gastric juice containing bile were rejected.

When such gastric juice was incubated with an equal quantity of 1 per cent casein solution at $\mathrm{pH} 7.4$, activity was indicated by certain obvious physical changes. The slightly opalescent digestion mixtures became chalky white. The curdy, white precipitate formed in serial samples when removed and treated with trichloracetic acid progressively decreased. There was a progressive increase in the turbidity of such trichloracetic acid filtrates. Centrifugation for 30 minutes at 2500 r.p.m. failed to remove the turbidity, and thereafter no precipitate appeared on standing for as long as 24 hours.

Coincident with these physical changes there occurred an increase in the total nitrogen in the trichloracetic acid filtrates. The results of 7 experiments are shown in Table I. The variation in the amount of total filtrable nitrogen produced by samples of gastric juice obtained from the 
TABLE I

Effect of incubation of normal human gastric juice at $37.5^{\circ} \mathrm{C}$. and $\mathrm{pH} 7.4$ with equal quantity of 1 per cent casein solution

\begin{tabular}{|c|c|c|c|c|c|c|}
\hline \multirow{2}{*}{$\begin{array}{c}\text { Experiment } \\
\text { number }\end{array}$} & \multicolumn{6}{|c|}{$\begin{array}{c}\text { Increase in nitrogen in trichloracetic acid filtrates } \\
(\mathrm{mgm} . \mathrm{per} 100 \mathrm{ml} \text {. digest) }\end{array}$} \\
\hline & $\begin{array}{c}1 \\
\text { hour }\end{array}$ & $\stackrel{2}{2}$ & $\begin{array}{c}3 \\
\text { hours }\end{array}$ & $\stackrel{4}{4}$ & $\begin{array}{c}5 \\
\text { hours }\end{array}$ & $\begin{array}{c}24 \\
\text { hours }\end{array}$ \\
\hline $\begin{array}{c}1 \\
2 \\
6^{*} \\
10^{*} \\
14^{*} \\
24^{*} \\
29\end{array}$ & $\begin{array}{l}5.2 \\
2.4 \\
6.0 \\
6.7 \\
9.0 \\
8.5 \\
2.5\end{array}$ & $\begin{array}{r}15.8 \\
8.0 \\
8.6 \\
9.6 \\
11.9 \\
5.0\end{array}$ & $\begin{array}{r}17.8 \\
9.8 \\
12.5 \\
23.4 \\
23.0 \\
10.5 \\
8.3\end{array}$ & $\begin{array}{r}13.8 \\
18.7 \\
14.1 \\
40.5 \\
20.5 \\
7.6\end{array}$ & $\begin{array}{r}16.5 \\
18.8 \\
44.5 \\
19.0 \\
7.6\end{array}$ & $\begin{array}{l}36.8 \\
40.6 \\
23.2 \\
42.7 \\
49.8 \\
33.0 \\
40.0\end{array}$ \\
\hline
\end{tabular}

* The samples of gastric juice used in Experiments 6 , 10,14 and 24 were obtained on different days from the same donor.

same donor on different occasions is shown by the results in Experiments 6, 10,14 and 24. The results of additional experiments in which normal, untreated gastric juice was employed as a control will be found in subsequent tables.

The intrinsic factor of normal human gastric juice is clinically active, as was gastric juice in vitro on casein at $p H 7.4$ under the following circumstances.

In unpublished clinical observations, we have found that normal human gastric juice after passage through a Berkefeld $V$ filter at a temperature not above $15^{\circ} \mathrm{C}$. contains intrinsic factor. As shown in Table II, Experiment 19, gastric juice after such treatment was active on casein.

Flood and West (3) have shown that normal human gastric juice after standing at room temperature at $p H 10$ for 30 minutes contains intrinsic factor. Similar results have been obtained by Ungley and Moffett (5). As shown in Table II, Experiments $33 \mathrm{a}$ and $35 \mathrm{c}$, the in vitro activity of gastric juice was retained after such treatment. The activity of an unfiltered portion of the sample employed in Experiment 35c was not significantly greater (cf. Experiment 35a).

Helmer, Fouts and Zerfas (13) have shown that the removal of pepsin and rennin from normal human gastric juice by precipitation with Hammarsten casein solution at about $\mathrm{pH} 4.7$ allows intrinsic factor to pass into the filtrate, as determined by clinical observations. In making such preparations it is essential to keep the temperature below $10^{\circ} \mathrm{C}$. in order to prevent hydroly-
TABLE II

Positive effect of incubation with equal quantity of 1 per cent casein solution at $37.5^{\circ} \mathrm{C}$. and $\mathrm{pH} 7.4$ of preparations of gastric juice clinically effective with extrinsic factor in pernicious anemia

\begin{tabular}{|c|c|c|c|c|c|}
\hline \multirow{3}{*}{$\begin{array}{c}\text { Experi- } \\
\text { ment } \\
\text { num- } \\
\text { ber }\end{array}$} & \multirow{3}{*}{$\begin{array}{l}\text { Method of preparation } \\
\text { of gastric juice and } \\
\text { reference to clinical } \\
\text { observation }\end{array}$} & \multirow{2}{*}{\multicolumn{2}{|c|}{$\begin{array}{c}\text { Increase in } \\
\text { nitrogen in } \\
\text { trichloracetic } \\
\text { acid filtrates } \\
\text { (mgm. per } 10\end{array}$}} & \multicolumn{2}{|c|}{$\begin{array}{l}\text { Increase in } \\
\text { amino nitrogen } \\
\text { by formol } \\
\text { titration }\end{array}$} \\
\hline & & & & 0 ml. dis & est) \\
\hline & & 4 hours & 24 hours & 4 hours & 24 hours \\
\hline 19 & $\begin{array}{l}\text { Passage through } \\
\text { Berkefeld V filter } \\
\text { (see text) }\end{array}$ & 30.9 & 58.4 & 0.0 & 0.5 \\
\hline $\begin{array}{l}33 a \\
35 c \\
38 c\end{array}$ & $\begin{array}{l}\text { Incubation at } \mathrm{pH} \\
10 \text { for } 30 \text { minutes } \\
(3,5)\end{array}$ & $\begin{array}{l}26.7 \\
23.5 \\
15.3\end{array}$ & $\begin{array}{l}52.1 \\
38.1 \\
40.5\end{array}$ & $\begin{array}{l}0.1 \\
0.0\end{array}$ & $\begin{array}{l}1.0 \\
0.0\end{array}$ \\
\hline $\begin{array}{l}35 a \\
38 a\end{array}$ & $\begin{array}{l}\text { Control-normal } \\
\text { gastric juice }\end{array}$ & $\begin{array}{l}27.1 \\
12.8\end{array}$ & $\begin{array}{l}40.1 \\
38.2\end{array}$ & $\begin{array}{l}0.0 \\
0.0\end{array}$ & $\begin{array}{l}1.1 \\
0.5\end{array}$ \\
\hline $\begin{array}{l}24 b \\
31 b \\
32 b\end{array}$ & $\begin{array}{l}\text { Filtrate from iso- } \\
\text { electric precipita- } \\
\text { tion casein (13) }\end{array}$ & $\begin{array}{l}21.0 \\
36.5 \\
17.8\end{array}$ & $\begin{array}{l}27.5 \\
48.8 \\
57.0\end{array}$ & & \\
\hline $\begin{array}{l}31 \mathrm{c} \\
32 \mathrm{c}\end{array}$ & $\begin{array}{l}\text { Filtrate from iso- } \\
\text { electric precipita- } \\
\text { tion casein } \\
\text { treated with } \\
\text { basic magnesium } \\
\text { carbonate }(9,14)\end{array}$ & $\begin{array}{l}27.5 \\
21.9\end{array}$ & $\begin{array}{l}51.0 \\
54.1\end{array}$ & & \\
\hline $\begin{array}{l}24 a \\
31 a \\
32 a\end{array}$ & $\begin{array}{l}\text { Control-normal } \\
\text { gastric juice }\end{array}$ & $\begin{array}{l}20.5 \\
45.5 \\
36.6\end{array}$ & $\begin{array}{l}33.0 \\
47.5 \\
45.2\end{array}$ & & \\
\hline
\end{tabular}

sis of the casein. As shown in Table II, Experiments $24 \mathrm{~b}, 31 \mathrm{~b}$, and $32 \mathrm{~b}$, after such treatment the in vitro activity of gastric juice on casein was retained. Similarly, we $(9,14)$ have found that subsequent treatment of the filtrate with basic magnesium carbonate does not destroy the intrinsic factor in the filtrate, as determined by clinical observation. As shown in Table II, Experiments $31 \mathrm{c}$ and $32 \mathrm{c}$, gastric juice so treated retained its activity in vitro on casein. The results of control observations with untreated samples of gastric juice are shown in Table II, Experiments 24a, 31a, and 32a.

The intrinsic factor of normal human gastric juice as determined by clinical observations, as well as the in vitro activity of gastric juice on casein at $p H 7.4$, is destroyed by the following procedures.

Partial destruction of the clinical activity of intrinsic factor by incubation of gastric juice at $37.5^{\circ} \mathrm{C}$. and $\mathrm{pH} 2.5$ to 3.5 for 2 hours has been observed (7). Likewise, such incubation defi- 
nitely diminished the subsequent in vitro activity of gastric juice on casein, as shown in Table III, Expèriments $15 \mathrm{~b}$ and $35 \mathrm{~b}$.

Complete destruction of the clinical activity of intrinsic factor by incubation of gastric juice at $40^{\circ} \mathrm{C}$. and $p H 1.8$ for 72 hours has been demonstrated $(9,14)$. Likewise, gastric juice so treated showed no significant in vitro activity on casein (Table III, Experiments 15c and 34b).

TABLE III

Negative effect of incubation with equal quantity of 1 per cent casein solution at $37.5^{\circ} \mathrm{C}$. and $\mathrm{pH} 7.4$ of preparations of gastric juice not clinically effective with extrinsic factor in pernicious anemia

\begin{tabular}{|c|c|c|c|c|c|}
\hline \multirow[t]{2}{*}{$\begin{array}{c}\text { Experi- } \\
\text { ment } \\
\text { num- } \\
\text { ber }\end{array}$} & \multirow[t]{2}{*}{$\begin{array}{l}\text { Method of preparation } \\
\text { of gastric juice and } \\
\text { reference to clinical } \\
\text { observation }\end{array}$} & \multicolumn{2}{|c|}{$\begin{array}{c}\text { Increase in } \\
\text { nitrogen in } \\
\text { trichloracetic } \\
\text { acid filtrates } \\
\quad(m g m . \text { per } 10\end{array}$} & \multicolumn{2}{|c|}{$\begin{array}{l}\text { Increase in } \\
\text { amino nitrogen } \\
\text { by formol } \\
\text { titration } \\
\text { (ml. digest) }\end{array}$} \\
\hline & & 4 hours & 24 hours & 4 hours & 24 hours \\
\hline $\begin{array}{l}15 \mathrm{~b} \\
35 \mathrm{~b}\end{array}$ & $\begin{array}{l}37.5^{\circ} \mathrm{C} \text {., pH } 1.5 \text { for } \\
2 \text { hours (7) }\end{array}$ & $\begin{array}{l}4.8 \\
4.0\end{array}$ & $\begin{array}{r}17.2 \\
0.5\end{array}$ & $\begin{array}{l}0.0 \\
0.0\end{array}$ & $\begin{array}{l}0.5 \\
0.0\end{array}$ \\
\hline $\begin{array}{l}15 c \\
34 b\end{array}$ & $\begin{array}{c}37.5^{\circ} \mathrm{C} ., \mathrm{pH} 1.5 \text { for } \\
72 \text { hours }(9,14)\end{array}$ & $\begin{array}{l}0.0 \\
2.8\end{array}$ & $\begin{array}{l}2.0 \\
2.6\end{array}$ & $\begin{array}{l}0.0 \\
0.0\end{array}$ & $\begin{array}{l}0.1 \\
0.0\end{array}$ \\
\hline $\begin{array}{l}15 \mathrm{a} \\
35 \mathrm{a}\end{array}$ & $\begin{array}{l}\text { Control-normal } \\
\text { gastric juice }\end{array}$ & $\begin{array}{l}40.5 \\
27.1\end{array}$ & $\begin{array}{l}49.8 \\
40.1\end{array}$ & $\begin{array}{l}0.0 \\
0.0\end{array}$ & $\begin{array}{l}1.4 \\
1.1\end{array}$ \\
\hline $10 \mathrm{~b}$ & $\begin{array}{l}70^{\circ} \text { to } 80^{\circ} \mathrm{C} ., \mathrm{pH} 1.5 \\
\text { for } 30 \text { minutes } \\
(9,14)\end{array}$ & 1.3 & 3.8 & & \\
\hline $10 c$ & $\underset{(9)}{\text { Boiling } 5 \text { minutes }}$ & 3.7 & 3.7 & & \\
\hline
\end{tabular}

Experiments 15a and 35a demonstrate the activity of control samples of untreated gastric juice.

The clinical activity of normal human gastric juice is destroyed by heating to $70^{\circ}$ to $80^{\circ} \mathrm{C}$. for 30 minutes $(9,14)$. Such treatment likewise left no significant activity in gastric juice incubated in vitro with casein (Table III, Experiment 10b).

Normal human gastric juice which has been boiled for 5 minutes (9) no longer contains intrinsic factor, as determined by clinical observations. Likewise, boiling for 5 minutes destroyed the in vitro activity of gastric juice on casein, as shown in Table III, Experiment 10c.

Intrinsic factor has not been found by clinical observation in the following substances which likewise had no significant in vitro effect on casein at pH 7.4.

Normal human saliva is not a source of intrinsic factor (15); and when incubated with casein solution it had no significant activity (Table IV, Experiment 35d).

Parke-Davis pepsin (U.S.P.) does not contain intrinsic factor, according to clinical observations (15). Likewise, a 2.5 per cent solution of this preparation of pepsin in distilled water was without significant effect in vitro on casein at

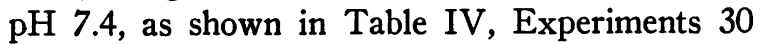
and $32 \mathrm{a}$.

TABLE IV

Negative effect of incubation with equal quantity of 1 per cent casein solution at $37.5^{\circ} \mathrm{C}$. and $p H 7.4$ of substances not clinically effective with extrinsic factor in pernicious anemia

\begin{tabular}{|c|c|c|c|c|c|}
\hline \multirow{2}{*}{$\begin{array}{c}\text { Experi- } \\
\text { ment } \\
\text { num- } \\
\text { ber }\end{array}$} & \multirow[t]{2}{*}{$\begin{array}{l}\text { Preparation and reference } \\
\text { to clinical observation }\end{array}$} & \multicolumn{2}{|c|}{$\begin{array}{c}\text { Increase in } \\
\text { nitrogen in } \\
\text { trichloracetic } \\
\text { acid filtrates } \\
\text { (mgm. per } 10\end{array}$} & \multicolumn{2}{|c|}{$\begin{array}{l}\text { Increase in } \\
\text { amino nitro- } \\
\text { gen by formol } \\
\text { titration } \\
0 \text { ml. digest })\end{array}$} \\
\hline & & $\begin{array}{c}4 \\
\text { hours }\end{array}$ & $\begin{array}{c}24 \\
\text { hours }\end{array}$ & $\begin{array}{c}4 \\
\text { hours }\end{array}$ & $\begin{array}{c}24 \\
\text { hours }\end{array}$ \\
\hline 35d & Normal human saliva (15) & 2.7 & 8.1 & 0.0 & 0.1 \\
\hline $\begin{array}{l}30 \\
32 a\end{array}$ & $\begin{array}{l}\text { Pepsin solution (2.5 per } \\
\text { cent) }(15)\end{array}$ & $\begin{array}{l}0.0 \\
0.0\end{array}$ & $\begin{array}{l}2.9 \\
0.0\end{array}$ & & 1.2 \\
\hline $\begin{array}{l}40 \mathrm{~b} \\
41 \mathrm{~b}\end{array}$ & $\begin{array}{l}\text { Pernicious anemia gastric } \\
\text { juice containing duo- } \\
\text { denal secretion after in- } \\
\text { cubation at pH } 10 \text { for } \\
2 \text { hours }\end{array}$ & $\begin{array}{l}0.9 \\
0.0\end{array}$ & $\begin{array}{l}3.5 \\
8.0\end{array}$ & $\begin{array}{l}0.6 \\
0.0\end{array}$ & $\begin{array}{l}0.4 \\
0.0\end{array}$ \\
\hline $\begin{array}{l}40 a \\
41 a\end{array}$ & $\begin{array}{l}\text { Control-untreated per- } \\
\text { nicious anemia gastric } \\
\text { juice containing duo- } \\
\text { denal secretion }\end{array}$ & $\begin{array}{l}67.3 \\
25.0\end{array}$ & $\begin{array}{l}69.1 \\
24.1\end{array}$ & $\begin{array}{r}8.5 \\
12.9\end{array}$ & $\begin{array}{l}22.8 \\
23.4\end{array}$ \\
\hline $\begin{array}{l}37 \mathrm{~b} \\
39 \mathrm{~b} \\
44 \mathrm{~b}\end{array}$ & $\begin{array}{l}\text { Control-normal gastric } \\
\text { juice containing duo- } \\
\text { denal secretion }\end{array}$ & 50.6 & 57.8 & $\begin{array}{r}16.1 \\
12.6 \\
9.0\end{array}$ & $\begin{array}{l}21.0 \\
15.5 \\
12.4 \\
\end{array}$ \\
\hline $\begin{array}{l}37 a \\
39 a \\
44 a\end{array}$ & $\begin{array}{l}\text { Control-normal gastric } \\
\text { juice containing duo- } \\
\text { denal secretion after in- } \\
\text { cubation at pH } 10 \text { for } \\
2 \text { hours }\end{array}$ & 56.7 & 57.8 & $\begin{array}{l}5.2 \\
3.9 \\
1.5\end{array}$ & $\begin{array}{l}7.4 \\
3.7 \\
2.4\end{array}$ \\
\hline
\end{tabular}

Since the administration of beef muscle alone to patients with addisonian pernicious anemia does not produce hematopoietic effects, it has been inferred that intrinsic factor is diminished $(7,16)$ or is absent (1) in the gastric secretion in addisonian pernicious anemia. From each of two patients with pernicious anemia $50 \mathrm{ml}$. of gastric secretion were obtained by prolonged suction. The material in each instance obviously contained bile and when incubated with casein at $\mathrm{pH} 7.4$ produced increases in both total nitrogen and amino nitrogen (Table IV, Experiments $40 \mathrm{a}$ and 41a). Since normal gastric secretion purposely 
contaminated with duodenal contents likewise produced increases in both total nitrogen and amino nitrogen, as shown in Table IV, Experiment 44a, it became necessary to distinguish between the activity of regurgitated duodenal contents and that of gastric secretion at $\mathrm{pH}$ 7.4. Northrop (17) has shown that exposure to alkali at $\mathrm{pH} 10$ or above at $40^{\circ} \mathrm{C}$. for 30 minutes destroys from 70 to 80 per cent of trypsin in solution. According to clinical observations $(3,5)$, intrinsic factor is not destroyed by such treatment nor, as shown in Table II, Experiments 33a and 35c, was the subsequent in vitro activity of normal human gastric juice on casein at $\mathrm{pH} 7.4$ significantly affected. Application of this technique to normal human gastric secretion purposely contaminated with duodenal contents did not significantly decrease the total filtrable nitrogen produced (Table IV, Experiment 44b) but greatly reduced the production of amino nitrogen, as shown in Table IV, Experiments $37 \mathrm{~b}, 39 \mathrm{~b}$, and $44 \mathrm{~b}$. On the other hand, exposure of the gastric secretions from the two patients with pernicious anemia to $\mathrm{pH} 10$ not only reduced subsequent amino nitrogen production to a minimum but also greatly reduced the production of total nitrogen, as shown in Table IV, Experiments $40 \mathrm{~b}$ and $41 \mathrm{~b}$. Thus the activity of normal human gastric juice contaminated with duodenal contents appeared to be due to the combined action of gastric and duodenal factors, whereas the activity of the contaminated gastric secretion from patients with pernicious anemia appeared to be largely, if not entirely, due to the duodenal contents present.

The clinical activity of intrinsic factor is inhibited by an environment more acid than $p H 3.5$. Clinical observations (9) have shown that the daily oral administration to patients with pernicious anemia of mixtures of beef muscle and gastric juice at $\mathrm{pH} 1.8$ or 2.5 did not lead to the increased blood production observed when such mixtures were given at $\mathrm{pH} 5$ or 7 . Appropriate control observations led to the conclusion that this failure was not due to destruction of intrinsic factor, but rather to the unsuitability of the acid environment for the essential reaction between beef muscle and gastric juice, which apparently occurs when they are administered to the patient at $\mathrm{pH} 5$ or 7 . Likewise, no significant activity of pepsin-free gastric juice could be detected at $\mathrm{pH} 2.5$ by the following technique.

One hundred $\mathrm{ml}$. of gastric juice were incubated at $37.5^{\circ} \mathrm{C}$. and $\mathrm{pH} 10$ for 2 hours. Fifty $\mathrm{ml}$. were then incubated with $50 \mathrm{ml}$. of casein solution at $\mathrm{pH} 2.5$ for 24 hours without significant effect, as shown in Table V, Experiment $42 \mathrm{~b}$.

TABLE $V$

Negative effect of incubation of pepsin-free gastric juice at pH 2.5 with equal quantity of 1 per cent casein solution at $37.5^{\circ} \mathrm{C}$.

\begin{tabular}{|c|c|c|c|c|c|c|}
\hline \multirow[t]{2}{*}{$\begin{array}{c}\text { Experi- } \\
\text { ment } \\
\text { number }\end{array}$} & \multirow[t]{2}{*}{ Preparation of gastric juice } & \multirow[t]{2}{*}{$\begin{array}{l}\text { Di- } \\
\text { gest } \\
\text { DH }\end{array}$} & \multicolumn{2}{|c|}{$\begin{array}{c}\text { Increase in } \\
\text { nitrogen in } \\
\text { trichloracetic } \\
\text { acid filtrates } \\
\text { (mgm. per } 10\end{array}$} & \multicolumn{2}{|c|}{$\begin{array}{c}\text { Increase in } \\
\text { amino nitro- } \\
\text { gen by formo } \\
\text { titration } \\
\text { ml. digest) }\end{array}$} \\
\hline & & & $\begin{array}{c}4 \\
\text { hours }\end{array}$ & $\begin{array}{c}24 \\
\text { hours }\end{array}$ & $\begin{array}{c}4 \\
\text { hours }\end{array}$ & $\begin{array}{c}24 \\
\text { hours }\end{array}$ \\
\hline $42 b$ & Incubation at $\mathrm{pH} 10$ & 2.5 & 0.2 & 0.0 & 0.0 & 0.0 \\
\hline $42 a$ & $\begin{array}{l}\text { Incubation at } \mathrm{pH} 10 \\
\text { for } 2 \text { hours }\end{array}$ & 7.4 & 11.6 & 32.8 & 1.1 & 0.7 \\
\hline
\end{tabular}

The remaining $50 \mathrm{ml}$. of gastric juice, however, when digested with $50 \mathrm{ml}$. of casein solution at $\mathrm{pH} 7.4$, caused the usual significant production of total filtrable nitrogen, as shown in Table V, Experiment 42a.

Finally, it is necessary to report a variation between a clinical observation and an in vitro experiment. Helmer and Fouts (18) have recently reported that, as judged by its augmentation of the activity of liver extract in pernicious anemia, one-half to two-thirds of the intrinsic factor of gastric juice is removed by adsorption with Lloyd's reagent. According to the directions of Helmer and Fouts, samples of normal human gastric juice at $\mathrm{pH} 1.8$, and samples at $\mathrm{pH} 7.4$ with and without preliminary exposure to $\mathrm{pH} \mathrm{10,}$ were shaken with 10 grams of Lloyd's reagent per $100 \mathrm{ml}$. of gastric juice. Thereafter the Lloyd's reagent was removed by filtration. As shown in Table VI, Experiments 65, 67, 68, and 70, after treatment with Lloyd's reagent the activity of such preparations of gastric juice in vitro on casein at $\mathrm{pH} 7.4$ was absent or trivial in contrast to the activity of untreated control portions.

\section{Discussion}

The foregoing experiments demonstrate the consistent ability of normal human gastric juice 
to produce from casein solution, upon incubation at $\mathrm{pH} 7.4$, progressive increases in nitrogenous bodies not precipitable by trichloracetic acid. The fact that the gastric juice employed, which was visually, at least, free from bile, did not contain significant amounts of regurgitated duodenal secretion (trypsin or erepsin) is confirmed by the relatively slight production of amino nitrogen (Table II, Experiments 19 and 35a; Table III, Experiment 15a; Table VI, Experiments 65a,

TABLE VI

Negative effect of incubation with equal quantity of 1 per cent casein solution at $37.5^{\circ} \mathrm{C}$. and $\mathrm{pH} 7.4$ of gastric juice after treatment with Lloyd's reagent

\begin{tabular}{|c|c|c|c|c|c|}
\hline \multirow{3}{*}{$\begin{array}{c}\text { Experi- } \\
\text { ment } \\
\text { num- } \\
\text { ber }\end{array}$} & \multirow{3}{*}{$\begin{array}{l}\text { Method of preparation } \\
\text { of gastric juice }\end{array}$} & \multirow{2}{*}{\multicolumn{2}{|c|}{$\begin{array}{l}\text { Increase in } \\
\text { nitrogen in } \\
\text { trichhloracetic } \\
\text { acid filtrates } \\
\text { (mgm. per 1C }\end{array}$}} & \multicolumn{2}{|c|}{$\begin{array}{c}\text { Increase in } \\
\text { amino nitrogen } \\
\text { by formol } \\
\text { titration }\end{array}$} \\
\hline & & & & $0 \mathrm{ml} . \mathrm{dig}$ & gest) \\
\hline & & 4 hours & 24 hours & 4 hours & 24 hours \\
\hline $\begin{array}{l}67 \mathrm{~b} \\
70 \mathrm{~b}\end{array}$ & $\begin{array}{l}\text { Lloyd's reagent at } \\
\text { pH } 1.8(18)\end{array}$ & $\begin{array}{l}0.0 \\
0.0\end{array}$ & $\begin{array}{l}0.0 \\
0.0\end{array}$ & $\begin{array}{l}0.0 \\
0.0\end{array}$ & $\begin{array}{l}0.0 \\
0.0\end{array}$ \\
\hline $\begin{array}{l}65 b \\
70 c\end{array}$ & $\begin{array}{l}\text { Lloyd's reagent at } \\
\text { pH } 7.4\end{array}$ & $\begin{array}{l}0.04 \\
0.1\end{array}$ & $\begin{array}{l}0.3 \\
1.1\end{array}$ & $\begin{array}{l}0.0 \\
0.0\end{array}$ & $\begin{array}{l}0.0 \\
0.0\end{array}$ \\
\hline $68 \mathrm{~b}$ & $\begin{array}{l}\text { Lloyd's reagent at } \\
\mathrm{pH} 7.4 \text { after incu- } \\
\text { bation at pH } 10 \\
\text { for } 2 \text { hours }\end{array}$ & 0.0 & 0.2 & 0.0 & 0.0 \\
\hline $\begin{array}{l}67 a \\
70 a \\
65 a\end{array}$ & $\begin{array}{l}\text { Control-normal } \\
\text { gastric juice }\end{array}$ & $\begin{array}{r}3.9 \\
2.8 \\
52.5\end{array}$ & $\begin{array}{l}15.5 \\
12.3 \\
53.9\end{array}$ & $\begin{array}{l}0.0 \\
0.0 \\
1.0\end{array}$ & $\begin{array}{l}0.0 \\
0.0 \\
2.0\end{array}$ \\
\hline $68 a$ & $\begin{array}{l}\text { Control-normal } \\
\text { gastric juice after } \\
\text { incubation at pH } \\
10 \text { for } 2 \text { hours }\end{array}$ & 27.9 & 47.2 & 0.0 & 0.0 \\
\hline
\end{tabular}

67a, and 70a) despite considerable increases in total filtrable nitrogen. Although saliva was undoubtedly present in the samples of gastric juice employed, this secretion alone was shown to be incapable of significant activity on casein at $\mathrm{pH}$ 7.4 (Table IV, Experiment 35d). It thus appears reasonable to conclude that the active agent in the samples of normal human gastric contents was secreted by the stomach.

The use of washed casein (which is not vitamin free) as a substrate does not necessarily imply that as such casein is clinically an effective extrinsic factor. That the activity observed was in fact due to the presence of the so-called intrinsic factor has been established only so far as the correspondences between the in vitro observations presented above and the present clinical knowledge of the characteristics of the intrinsic factor allow such an inference. Since, according to Helmer and Fouts, only one-half to two-thirds of the intrinsic factor was removed by Lloyd's reagent, the total removal of the in vitro activity by this reagent in our hands needs further study. It is possible, however, that differences in the content of mucus or of other components of the gastric juice utilized, by interfering with the activity of Lloyd's reagent, may explain the differences in the results obtained.

Since our preliminary report (12), Dr. Fritz Lasch (19) of Vienna has published the results of independent observations on the activity of pepsin-free gastric secretion on powdered beef muscle and other substrates at $\mathrm{pH} 5.5$ to 6 . The gastric secretion of a variety of patients without anemia had significantly greater activity in producing nitrogen in trichloracetic acid filtrates of such digests than did samples of such gastric secretion after boiling. Moreover, filtrates from digests containing gastric juice from several patients with pernicious anemia showed little or no increases in nitrogen. In patients with hypochromic anemia and achylia and in patients with achylia without pernicious anemia the ability of the gastric secretion to produce nonprotein nitrogen agrees with certain clinical observations (20), demonstrating the presence of intrinsic factor. Thus, further significant correspondences between in vitro and clinical observations on intrinsic factor have been established by Lasch.

In connection with work demonstrating that the substance responsible for the blood forming activity of liver upon administration in pernicious anemia is probably an "albumose," Dakin, Ungley and West (21) have recently drawn attention to the work of Glaessner, who in 1902 described proteolytic activity in extracts of the gastric (22) and the duodenal (23) mucosa of the hog. This activity he ascribed to an enzyme which he called "pseudo pepsin." Glaessner found it active on protein in weakly acid or alkaline solution, and stated that the cleavage products contained tryptophane. Glaessner's work was partially confirmed by Reach (24) and Pekelharing (25). On the other hand, the existence of pseudo pepsin was denied by Klug (26), while Bergman (27) iden- 
tified it with erepsin. Subsequently, the finding of trypsin in gastric juice on occasion seemed to explain the proteolytic activity ascribed to pseudo pepsin. Since at that time there appeared to be no known physiological need for such an enzyme, further attempts to prove or disprove its existence were not made. In retrospect, however, the observations of Glaessner now appear to possess a renewed interest. It also now seems probable that Griffiths (10) was correct in reporting proteolytic activity of human gastric juice at $\mathrm{pH} 6$, despite the fact that his work could not be confirmed by Emerson and Helmer (11). Finally, since little or no amino nitrogen is produced from casein by the action of the gastric juice, the reason for our failure in 1930 to detect increases in the amino nitrogen content of digests of neutral mixtures of beef muscle and gastric juice now becomes obvious.

\section{B. THE NATURE OF THE in vitro ACTIVITY OF NOR- MAL HUMAN GASTRIC JUICE ON CASEIN AT $\mathrm{pH} 7.4$}

The foregoing observations strongly suggest that some factor in normal human gastric juice when incubated with casein solution at $\mathrm{pH} 7.4$ causes a progressive increase in the amount of nitrogen in the digest, which cannot be precipitated by trichloracetic acid. It is possible that because of the correspondence of such activity with the characteristics of the intrinsic factor, as determined by clinical observation, the same agent may be active in each instance. Certain other explanations must, however, be considered. It is possible that the increase in nonprecipitable nitrogen may have been due to (1) peptic hydrolysis, (2) differences in adsorption upon the protein substrate of soluble nitrogenous substances in different types or preparations of gastric juice (11), or (3) the action of tryptic or ereptic-like enzymes. Finally, it is to be emphasized that since only small increases in amino nitrogen have been observed, the finding of changes in the amount of nitrogenous material in the digest not precipitated by trichloracetic acid, as observed by Griffiths (10), Lasch (19) and ourselves (12), does not necessarily constitute a demonstration of proteolytic activity. Accordingly, with respect to our experiments, these possibilities were examined.

\section{Exclusion of pepsin}

Since it is generally conceded that pepsin possesses little activity at $\mathrm{pH}$ ranges greater than its isoelectric point ( $\mathrm{pH} 4.7)$, this enzyme could scarcely have been responsible for the considerable activity observed in our digests at $\mathrm{pH}$ 7.4. Further proof of this is afforded by the negative results of incubation of a 2.5 per cent solution of

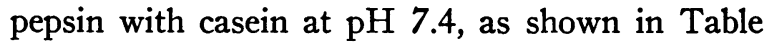
IV, Experiments 30 and 32a. Moreover, since pepsin is readily destroyed by alkali, the fact that exposure of the gastric juice to $\mathrm{pH} 10$ for 30 minutes did not significantly affect its subsequent activity at $\mathrm{pH} 7.4$ (Table II, Experiments 33a and $35 \mathrm{c}$ ) would appear to exclude pepsin. Again, after exposure of gastric juice to $\mathrm{pH} 10$ for 2 hours, its activity at $\mathrm{pH} 2.5$, as judged by the Mett's tube method or by incubation with casein, was completely destroyed (Table V, Experiment 42b), though its activity at $\mathrm{pH} 7.4$ on casein was retained (Table V, Experiment 42a).

\section{Exclusion of trypsin and erepsin}

Since samples of normal human gastric juice were discarded if visibly tinged with bile and since the increase in amino nitrogen from casein was trivial compared with the increase in total filtrable nitrogen (Table II, Experiments 19 and 35a; Table III, Experiment 15a; and Table VI, Experiments $65 \mathrm{a}, 67 \mathrm{a}$, and $70 \mathrm{a}$ ), significant contamination with duodenal contents would seem to have been excluded. However, the possibility that the activity demonstrated may have been due to a tryptic or ereptic-like enzyme of gastric origin needs consideration, especially as this supposition formed the basis of some of the objections $(26,27)$ to Glaessner's work. The fact that Northrop (17) has shown that between 70 and 80 per cent of trypsin in solution is destroyed by exposure to alkali at $\mathrm{pH} 10$ for 30 minutes at $40^{\circ} \mathrm{C}$. seemed to offer a method of discrimination. This procedure was therefore applied respectively to normal gastric juice, to normal gastric juice purposely contaminated with duodenal contents, and to gastric juice from two patients with pernicious anemia obviously containing regurgitated duodenal contents.

Preliminary exposure of gastric juice to alkali did not significantly affect the increases in nitrogen 
in trichloracetic acid filtrates of the digests (Table II, Experiments 33a, 35c, and 38c) compared with the activity of digests with untreated gastric juice (Table II, Experiments 35a and 38a). None of these digests of gastric juice after exposure to alkali, in contrast to those with gastric juice contaminated with duodenal secretion (Table IV, Experiments 37a, 39a, and 44a), showed significant production of amino nitrogen. Moreover, after exposure of the contaminated gastric juice to alkali, though the production of nitrogen in trichloracetic acid filtrates was not significantly affected (Table IV, Experiment 44a) the increase in amino nitrogen was greatly reduced (Table IV, Experiments 37a, 39a, and 44a). Finally, the gastric juice from patients with pernicious anemia which contained duodenal secretion produced, like contaminated normal gastric juice, increases in both total filtrable nitrogen and amino nitrogen (Table IV, Experiments 40a and 41a). After exposure to alkali, however, the secretion from the patients with pernicious anemia produced little or no total filtrable nitrogen or amino nitrogen on casein (Table IV, Experiments 40b and 41b). Thus, the results of these experiments apparently indicate that the activity of normal human gastric juice demonstrated above is not due to contamination with or to the natural presence of significant amounts of trypsin or erepsin acting in their accepted manner (28). Further evidence that the activity of normal human gastric juice did not resemble the activity of trypsin or erepsin was found in the fact that some activity is present at $\mathrm{pH} 5$ (Table VIII). Lastly, confirmation of this fact was obtained from a study of the nature of the digestion products and is presented immediately below.

\section{Evidence for proteolytic activity}

That differences in the adsorption upon the protein substrate of soluble nitrogenous substances from different types of gastric juice could have been responsible for the wide differences between active and inactive preparations of gastric juice did not seem likely. The very slight production of amino nitrogen, however, left incomplete the demonstration of hydrolysis of the casein by normal human gastric juice. Accordingly, fractionations of the nitrogenous material in the digests by means of certain portions of Wasteneys and Borsook's procedure (28) were made before and after incubation.

Mixtures of $50 \mathrm{ml}$. of normal human gastric juice and $50 \mathrm{ml}$. of 1 per cent casein solution were set up for incubation at $\mathrm{pH} 7.4$, as usual. Samples were taken at once and after 24 hours. The total nitrogen per $100 \mathrm{ml}$. of digest was first determined by micro-Kjeldahl method on a $0.5 \mathrm{ml}$. sample. The protein and metaprotein were precipitated from a $40 \mathrm{ml}$. sample by the addition of $10 \mathrm{ml}$. of 10 per cent trichloracetic acid. After standing for 1 hour, the contents of the flask were subjected to filtration. The difference between the total nitrogen and the nitrogen in the trichloracetic acid filtrate calculated in milligrams of nitrogen per $100 \mathrm{ml}$. of digest represented the protein and metaprotein nitrogen per $100 \mathrm{ml}$. of digest. Thirty-five $\mathrm{ml}$. of the trichloracetic acid filtrate were digested on the water bath at $100^{\circ} \mathrm{C}$. until freed from trichloracetic acid. The remaining solution was restored to its original volume by the addition of distilled water and placed in a $50 \mathrm{ml}$. Erlenmeyer flask. Twenty grams of powdered anhydrous sodium sulphate were added and the flask shaken in order to effect maximal solution. The flask was then placed in the incubator at $37.5^{\circ} \mathrm{C}$. for 1 hour and the precipitate removed by filtration. The nitrogen of this filtrate, calculated in terms of $100 \mathrm{ml}$. of digest, represented the peptone and subpeptone nitrogen. The difference between this value and that for the nitrogen in the trichloracetic acid filtrate, calculated in terms of $100 \mathrm{ml}$. of digest, represented the proteose nitrogen. In Table VII are shown the results of these procedures on the digests before and after incubation for 24 hours at $\mathrm{pH} 7.4$. The values are expressed as percentages of the total nitrogen of the digest represented by protein and metaprotein, by proteose, and by peptone and subpeptone, respectively. In addition, there are shown the percentages of amino nitrogen as determined by formol titration.

The data from Experiments 47, 49a, 51a, 52a, and $54 \mathrm{a}$ demonstrate that despite insignificant increases in the percentage of amino nitrogen, incubation of normal human gastric juice with casein solution resulted in hydrolysis which progressed chiefly to the proteose and peptone stage. Experiment $49 \mathrm{~b}$ demonstrates the lack of signifi- 
TABLE VII

Extent of hydrolysis at $37.5^{\circ} \mathrm{C}$. and $p H 7.4$ of 1 per cent casein solution by equal quantity of various preparations of gastric juice. Nitrogen partition as determined by modification of method of Wasteneys and Borsook

\begin{tabular}{|c|c|c|c|c|c|c|}
\hline \multirow[b]{2}{*}{$\begin{array}{c}\text { Experi- } \\
\text { ment } \\
\text { number }\end{array}$} & \multirow[b]{2}{*}{$\begin{array}{l}\text { Method of } \\
\text { preparation of } \\
\text { gastric juice }\end{array}$} & \multirow[b]{2}{*}{$\begin{array}{c}\text { Incu- } \\
\text { bation } \\
\text { time }\end{array}$} & \multicolumn{4}{|c|}{ Percentage of total nitrogen as } \\
\hline & & & $\begin{array}{l}\text { Protein } \\
\text { and } \\
\text { meta- } \\
\text { protein }\end{array}$ & $\begin{array}{c}\text { Pro- } \\
\text { teose }\end{array}$ & $\begin{array}{l}\text { Pep- } \\
\text { tone } \\
\text { and } \\
\text { sub- } \\
\text { pep- } \\
\text { tone }\end{array}$ & $\begin{array}{l}\text { Amino } \\
\text { nitro- } \\
\text { gen by } \\
\text { formol } \\
\text { titra- } \\
\text { tion * }\end{array}$ \\
\hline 47 & Normal & $\begin{array}{c}\text { hours } \\
0 \\
24\end{array}$ & $\begin{array}{l}\text { per cent } \\
83.00 \\
35.30\end{array}$ & $\begin{array}{l}\text { per cent } \\
15.20 \\
61.00\end{array}$ & $\begin{array}{c}\text { per cent } \\
1.88 \\
3.72\end{array}$ & per cent \\
\hline $51 a$ & Normal & $\begin{array}{r}0 \\
24\end{array}$ & $\begin{array}{l}76.05 \\
19.30\end{array}$ & $\begin{array}{l}14.50 \\
18.35\end{array}$ & $\begin{array}{r}9.00 \\
62.25\end{array}$ & $\begin{array}{r}7.54 \\
10.30\end{array}$ \\
\hline $49 a$ & Normal & $\begin{array}{r}0 \\
24\end{array}$ & $\begin{array}{l}79.40 \\
10.37\end{array}$ & $\begin{array}{l}19.75 \\
62.00\end{array}$ & $\begin{array}{r}0.78 \\
27.70\end{array}$ & $\begin{array}{r}8.52 \\
10.05\end{array}$ \\
\hline 49b & $\begin{array}{l}\text { Boiled } 5 \text { min- } \\
\text { utes }\end{array}$ & $\begin{array}{r}0 \\
24\end{array}$ & $\begin{array}{l}78.20 \\
77.60\end{array}$ & $\begin{array}{l}20.80 \\
17.50\end{array}$ & $\begin{array}{l}1.12 \\
5.14\end{array}$ & $\begin{array}{l}7.86 \\
7.86\end{array}$ \\
\hline $52 \mathrm{a}$ & Normal & $\begin{array}{r}0 \\
24\end{array}$ & $\begin{array}{l}80.75 \\
22.75\end{array}$ & $\begin{array}{r}5.44 \\
36.85\end{array}$ & $\begin{array}{l}13.84 \\
40.45\end{array}$ & $\begin{array}{l}7.92 \\
9.92\end{array}$ \\
\hline $52 \mathrm{~b}$ & $\begin{array}{l}\text { Incubation at } \\
\text { pH } 10 \text { for } 2 \\
\text { hours }\end{array}$ & $\begin{array}{r}0 \\
24\end{array}$ & $\begin{array}{l}81.35 \\
31.75\end{array}$ & $\begin{array}{r}2.60 \\
19.85\end{array}$ & $\begin{array}{l}14.95 \\
45.11\end{array}$ & $\begin{array}{l}7.14 \\
8.26\end{array}$ \\
\hline $54 a$ & Normal & $\begin{array}{r}0 \\
24\end{array}$ & $\begin{array}{l}73.65 \\
12.45\end{array}$ & $\begin{array}{r}5.75 \\
63.95\end{array}$ & $\begin{array}{l}20.55 \\
23.62\end{array}$ & $\begin{array}{l}8.40 \\
9.00\end{array}$ \\
\hline $54 \mathrm{~b}$ & $\begin{array}{l}\text { Incubation at } \\
\mathrm{pH} 10 \text { for } 2 \\
\text { hours }\end{array}$ & $\begin{array}{r}0 \\
24\end{array}$ & $\begin{array}{l}79.00 \\
12.89\end{array}$ & $\begin{array}{r}7.65 \\
55.17\end{array}$ & $\begin{array}{l}13.64 \\
31.94\end{array}$ & $\begin{array}{l}8.00 \\
8.58\end{array}$ \\
\hline
\end{tabular}

* The percentage of amino nitrogen determined by formol titration is of course included under subpeptone nitrogen determined by the procedure of Wasteneys and Borsook (28).

cant activity with boiled gastric juice. Experiments $52 \mathrm{~b}$ and $54 \mathrm{~b}$ demonstrate that previous exposure to $\mathrm{pH} 10$ for 2 hours, though completely destroying pepsin and, according to Northrop, destroying from 70 to 80 per cent of any trypsin present, did not significantly affect the activity of the gastric juice, as had also been shown above in Table II, Experiments 33a, 35c, and 38c.

\section{$p H$ range of activity}

Experiments to determine the $\mathrm{pH}$ range over which activity could be observed were undertaken. A $75 \mathrm{ml}$. sample of gastric juice was exposed to $\mathrm{pH} 10$ for 2 hours at $37.5^{\circ} \mathrm{C}$. in order to destroy pepsin and to minimize any tryptic or ereptic activity. Thereafter the gastric juice was brought to $\mathrm{pH} 7.4$ and mixed with an equal quantity of casein solution at $\mathrm{pH} 7.4$. A $5 \mathrm{ml}$. sample was at once removed for determination of the initial total filtrable nitrogen. From the remainder of the mixture $15 \mathrm{ml}$. samples were removed to test tubes and the reaction of each sample adjusted as rapidly as possible to several values, ranging from $\mathrm{pH} 2.5$ to 10 . After incubation at $37.5^{\circ} \mathrm{C}$. for 24 hours the amounts of total filtrable nitrogen and of amino nitrogen in the contents of each tube were determined. In Table VIII are shown

TABLE VIII

Effect of $\mathrm{pH}$ of digest on activity of pepsin-free gastric juice on equal quantity of 1 per cent casein solution at $37.5^{\circ} \mathrm{C}$.

\begin{tabular}{c|c|c|c|c|c|c|c}
\hline \hline $\begin{array}{c}\text { Experiment } \\
\text { number }\end{array}$ & \multicolumn{6}{|c}{$\begin{array}{c}\text { Increase in nitrogen in trichloracetic acid filtrates } \\
\text { after } 24 \text { hours } \\
\text { (mgm. per 100 ml. digest) }\end{array}$} \\
\cline { 2 - 7 } & pH 10 & $\mathrm{pH} 8$ & $\mathrm{pH} 7.4$ & $\mathrm{pH} 6$ & $\mathrm{pH} 5$ & $\mathrm{pH} 4.5$ & $\mathrm{pH} 2.5$ \\
\hline 46 & 42.1 & 49.2 & 43.0 & & 10.0 & 2.4 & 0.0 \\
50 & 10.7 & 13.4 & 15.3 & 11.4 & 1.8 & 0.6 & 0.0 \\
53 & 52.5 & 47.9 & 27.3 & 24.5 & 19.7 & 2.0 & 1.5 \\
\hline
\end{tabular}

the increases in terms of milligrams of nitrogen per $100 \mathrm{ml}$. of digest at the various $\mathrm{pH}$ values. It is apparent that below $\mathrm{pH} 4.5$ there was very little activity. The optimal reaction for activity with casein as substrate was apparently in the vicinity of $\mathrm{pH} 8$.

\section{Discussion}

The evidence presented above apparently demonstrates that the production of nitrogenous substances not precipitable by trichloracetic acid in digests of normal human gastric juice and casein at $\mathrm{pH} 7.4$ is due to hydrolysis of the casein and not merely to physical changes in the adsorbability of nitrogenous constituents of the digests. The evidence is regarded as consistent with the action of a proteolytic enzyme. The fact that after 24 hours at $37.5^{\circ} \mathrm{C}$. relatively little amino nitrogen was produced and that according to a modification of the method of Wasteneys and Borsook the hydrolysis of the casein during this time progressed chiefly to the stage of proteoses and peptones suggests the action of an enzyme resembling pepsin rather than trypsin or erepsin. Indeed, Hunter and Smith (29) have shown that trypsin incubated at $37.5^{\circ} \mathrm{C}$. and $\mathrm{pH} 8$ with casein solution unmasks half of the amino groups within an hour. Although the hydrolysis thus re- 
sembles in its time relations that produced by pepsin, the fact that the subsequent activity of the gastric juice was not significantly affected by exposure to alkali and that thereafter activity was maximal at about $\mathrm{pH} 8$ and absent at $\mathrm{pH} 2.5$ would appear to exclude pepsin acting in its usual manner. Pepsinogen should have been entirely converted to pepsin by the natural acidity of the gastric juice and would then have been destroyed by the alkali. If any pepsinogen had remained unconverted to pepsin, it should have become active as pepsin when the gastric juice was brought to $\mathrm{pH} 2.5$. It thus appears that a type of proteolysis resembling that of pepsin in acid solution occurs when normal human gastric juice acts upon casein in a neutral environment. Whether or not there is any relationship between the enzyme reported by Glaessner in 1902 and the proteolytic activity of gastric juice described in this communication remains to be determined.

\section{CONCLUSIONS}

1. Incubation at $37.5^{\circ} \mathrm{C}$. and $\mathrm{pH} 7.4$ of equal quantities of normal human gastric juice and 1 per cent casein solution results in progressive increases in the nitrogenous substances in trichloracetic filtrates of such digests.

2. This activity of normal human gastric secretion, like that of the so-called intrinsic factor, is apparently $(a)$ independent of the presence of saliva and of regurgitated duodenal contents; $(b)$ absent or greatly diminished in the gastric secretion of patients with addisonian pernicious anemia, according to our observations and those of Lasch; (c) not destroyed by Berkefeld filtration or exposure to alkali; destroyed by exposure to $40^{\circ} \mathrm{C}$. for 72 hours, or to $70^{\circ}$ to $80^{\circ} \mathrm{C}$. for 30 minutes, or by boiling for 5 minutes; and $(d)$ inhibited by an environment more acid than $\mathrm{pH}$ 3.5.

3. The in vitro activity of normal human gastric juice is entirely removed by treatment with Lloyd's reagent, which, however, Helmer and Fouts have shown by clinical test to effect only partial removal of the intrinsic factor.

4. As determined by a modification of the nitrogen partition method of Wasteneys and Borsook, hydrolysis of casein by gastric juice at $37.5^{\circ} \mathrm{C}$. and $\mathrm{pH} 7.4$ progresses within 24 hours chiefly to the stage of proteoses and peptones, with production of relatively little amino nitrogen.

5. This evidence is regarded as consistent with the action of a proteolytic enzyme.

6. The proteolysis observed is considered not to be due to pepsin acting in its accepted manner because the activity was not significantly affected by exposure to alkali and thereafter was maximal at about $\mathrm{pH} 8$ and absent at $\mathrm{pH} 2.5$.

7. The proteolysis observed is considered not to be due to tryptic or ereptic-like enzymes acting in their accepted manner because the activity was not significantly affected by exposure to alkali, because thereafter significant activity was ob-

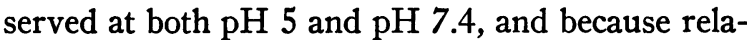
tively little amino nitrogen was produced within 24 hours at $37.5^{\circ} \mathrm{C}$.

\section{BIBLIOGRAPHY}

1. Castle, W. B., Observations on the etiologic relationship of achylia gastrica to pernicious anemia. I. The effect of the administration to patients with pernicious anemia of the contents of the normal human stomach recovered after the ingestion of beef muscle. Am. J. M. Sc., 1929, 178, 748.

2. Castle, W. B., and Townsend, W. C., Idem. II. The effect of the administration to patients with pernicious anemia of beef muscle after incubation with normal human gastric juice. Am. J. M. Sc., 1929, 178, 764.

3. Flood, Charles, and West, Randolph, Some properties of Castle's intrinsic factor. Proc. Soc. Exper. Biol. and Med., 1936, 34, 542.

4. Hanes, F. M., Hansen-Prüss, O. C., and Edwards, J. W., The feeding of modified gastric juice in pernicious anemia. J. A. M. A., 1936, 106, 2058.

5. Ungley, C. C., and Moffett, Robert, Observations on Castle's intrinsic factor in pernicious anaemia. Lancet, 1936, 1, 1232.

6. Fitz-Hugh, Thomas, Jr., and Creskoff, A. J., Experiments with "depepsinized" human gastric juice in the treatment of pernicious anemia. Am. J. M. Sc., 1936, 192, 168.

7. Castle, W. B., and Ham, T. H., Observations on the etiologic relationship of achylia gastrica to pernicious anemia. V. Further evidence for the essential participation of extrinsic factor in hematopoietic responses to mixtures of beef muscle and gastric juice and to hog stomach mucosa. J. A. M. A., 1936, 107, 1456.

8. Klein, L., and Wilkinson, J. F., Investigations on the nature of haemopoietin, the anti-anaemic substance in hog's stomach. II. The production of a thermostable haemopoietically active substance similar to or identical with the anti-anaemic principle of liver by the action of the thermolabile haemopoietin on beef. Biochem. J., 1934, 28, 1684. 
9. Castle, W. B., Heath, C. W., Strauss, M. B., and Heinle, R. W., Observations on the etiologic relationship of achylia gastrica to pernicious anemia. VI. The site of the interaction of food (extrinsic) and gastric (intrinsic) factors; failure of in vitro incubation to produce a thermostable hematopoietic principle. Am. J. M. Sc., 1937, 194, 618.

10. Griffiths, W. J., The action of gastric juice on beef muscle-globulin, with reference to anaemia. Biochem. J., 1934, 28, 671.

11. Emerson, C. P., and Helmer, O. M., The proteolytic effect of normal gastric juice on beef muscle globulin, with reference to the reported action of the anti-anemic intrinsic factor. Am. J. Digest. Dis. and Nutrition, 1936, 3, 753.

12. Taylor, F. H. L., Castle, W. B., Heinle, R. W., and Adams, M. A., Correlation of in vitro activity of normal human gastric juice on casein at $\mathrm{pH} 7.4$ with gastric intrinsic factor. Proc. Soc. Exper. Biol. and Med., 1937, 36, 566.

13. Helmer, O. M., Fouts, P. J., and Zerfas, L. G., The relationship of the intrinsic factor to a hematopoietic material in concentrated human gastric juice. Am. J. M. Sc., 1934, 188, 184.

14. Castle, W. B., Townsend, W. C., and Heath, C. W., Further observations on the etiological relationship of achylia gastrica to pernicious anemia. J. Clin. Invest. (Proc.), 1930, 9, 2.

15. Castle, W. B., Townsend, W. C., and Heath, C. W., Observations on the etiologic relationship of achylia gastrica to pernicious anemia. III. The nature of the reaction between normal human gastric juice and beef muscle leading to clinical improvement and increased blood formation similar to the effect of liver feeding. Am. J. M. Sc., 1930, 180, 305.

16. Goldhamer, S. M., The presence of the intrinsic factor of Castle in the gastric juice of patients with pernicious anemia. Am. J. M. Sc., 1936, 191, 405.
17. Northrop, J. H., The inactivation of trypsin. III. Spontaneous inactivation. J. Gen. Physiol., 192122, 4, 261.

18. Helmer, O. M., and Fouts, P. J., Fractionation studies on intrinsic factor in normal human gastric juice. Am. J. M. Sc., 1937, 194, 399.

19. Lasch, Fritz, Uber eine biochemische Methode zur quantitativen Bestimmung des "intrinsic factor" nach Castle im Magensaft. Klin. Wchnschr., 1937, 16, 810.

20. Hartfall, S. J., and Witts, L. J., The intrinsic factor of Castle in simple achlorhydric anaemia. Guy's Hosp. Rep., 1933, 83, 24.

21. Dakin, H. D., Ungley, C. C., and West, Randolph, Further observations on the chemical nature of a hematopoietic substance occurring in liver. J. Biol. Chem., 1936, 115, 771.

22. Glaessner, Karl, Utber die Vorstufen der Magenfermente. Beitr. z. chem. Physiol. u. Path., 1902, 1, 1. Uber die örtliche Verbreitung der Profermente in der Magenschleimhaut. Ibid., p. 24.

23. Glaessner, Karl, Uber die Funktion der Brunnerschen Drüsen. Beitr. z. chem. Physiol. u. Path., 1902, 1, 105.

24. Reach, Felix, Zur Kenntnis der Verdauungs- und Resorptionsvorgänge im Magen. Beitr. z. chem. Physiol. u. Path., 1904, 4, 139.

25. Pekelharing, C. A., A propos de la pepsine. Arch. di sc. biol., 1905,11 , Suppl. p. 36.

26. Klug, F., Ueber das Ferment der Pylorusschleimhaut. Arch. f. d. ges. Physiol., 1902, 92, 281.

27. Bergman, P., Studien über die Digestion der Pflanzenfresser. Skandinav. Arch. f. Physiol., 1906, 18, 119.

28. Wasteneys, Hardolph, and Borsook, Henry, A method for the fractional analysis of incomplete protein hydrolysates. J. Biol. Chem., 1924-25, 62, 1.

29. Hunter, Andrew, and Smith, R. G., The liberation of ammonia in tryptic digestion. J. Biol. Chem., 1924-25, 62, 649. 